\title{
Evaluation of Magnesium Die-Casting Alloys for Elevated Temperature Applications: Microstructure, Tensile Properties, and Creep Resistance
}

\author{
SUMING ZHU, MARK A. EASTON, TREVOR B. ABBOTT, JIAN-FENG NIE, \\ MATTHEW S. DARGUSCH, NORBERT HORT, and MARK A. GIBSON
}

\begin{abstract}
Several families of magnesium die-casting alloys have been developed to operate at the elevated temperatures experienced in automotive powertrain applications. Most alloys are based on the Mg-Al system with alloying additions such as silicon, strontium, calcium, and rare earth elements (RE), although alloys with RE as the primary alloying constituent are also considered. This work presents an evaluation of the tensile properties and creep resistance of the most common magnesium die-casting alloys, in conjunction with the analysis of microstructure. The alloys investigated include AS31 (Mg-3Al-1Si), AJ52 (Mg-5Al-2Sr), MRI153A (Mg-9Al-1Ca0.1Sr), MRI153M (Mg-8Al-1Ca-0.3Sr), MRI230D (Mg-6.5Al-2Ca-1Sn-0.3Sr), AXJ530 (Mg5Al-3Ca-0.2Sr), AE42 (Mg-4Al-2RE), AE44 (Mg-4Al-4RE), and AM-HP2 + (Mg-3.5RE$0.4 \mathrm{Zn}$ ). It is shown that, among the various alloys evaluated, MRI230D, AXJ530, and AM-HP2 + have higher yield strength than the Al alloy A380, but the ductility is relatively low at room temperature for these alloys. In contrast, AS31 and the AE series alloys have very good room temperature ductility, but their yield strength is lower than that of A380. In terms of creep resistance, MRI230D, AXJ530, AE44, and AM-HP2 + are all comparable to the Al alloy counterpart at $423 \mathrm{~K}$ and $448 \mathrm{~K}\left(150{ }^{\circ} \mathrm{C}\right.$ and $\left.175^{\circ} \mathrm{C}\right)$. Microstructural factors that are most important to the strength and creep resistance of the $\mathrm{Mg}$ die-casting alloys are discussed.
\end{abstract}

DOI: $10.1007 / \mathrm{s} 11661-015-2946-9$

(c) The Minerals, Metals \& Materials Society and ASM International 2015

\section{INTRODUCTION}

AMONG the most attractive applications for magnesium alloys in the automobile industry are powertrain components where considerable weight reductions can be achieved, and it is in these applications where the greatest benefit from lightweighting can be achieved. ${ }^{[1-3]}$ For such applications, $\mathrm{Mg}$ alloys are required to possess excellent mechanical properties, especially elevated temperature creep resistance, since the operative temperatures are in the range of $423 \mathrm{~K}$ to $473 \mathrm{~K}\left(150{ }^{\circ} \mathrm{C}\right.$ to $\left.200{ }^{\circ} \mathrm{C}\right) \cdot{ }^{[4,5]}$

SUMING ZHU, Senior Research Fellow, and MARK A. EASTON, Professor and Deputy Head of School, are with the School of Aerospace, Mechanical and Manufacturing Engineering, RMIT University, Carlton, VIC 3053, Australia. Contact e-mail: mark.easton@rmit.edu.au TREVOR B. ABBOTT, Director - Research and Development, is with the Magontec Limited, Sydney, NSW 2000, Australia. JIAN-FENG NIE, Professor, is with the Department of Materials Engineering, Monash University, Melbourne, VIC 3800, Australia. MATTHEW S. DARGUSCH, Associate Professor, is with the School of Mechanical and Mining Engineering, The University of Queensland, Brisbane, QLD 4072, Australia. NORBERT HORT, Head Magnesium Processing Group, is with the Magnesium Innovation Centre, Helmholtz-Zentrum Geesthacht, Max-Planck-Straße 1, Geesthacht, Germany. MARK A. GIBSON, Senior Principal Research Scientist, is with the Department of Materials Engineering, Monash University, and also with the CSIRO Manufacturing Flagship, Clayton, VIC 3169, Australia.

Manuscript submitted October 25, 2014.

Article published online May 5, 2015
The most commonly used $\mathrm{Mg}$ alloys are those based on the Mg-Al system, for example, AZ91 (Mg-9Al-1Zn, compositions in weight pct hereafter unless specified) and AM60 (Mg-6Al-0.3Mn). These alloys have good mechanical properties at room temperature, excellent die-castability, and adequate corrosion resistance. However, $\mathrm{Mg}$-Al alloys are not suitable for use at elevated temperatures because, at temperatures above $373 \mathrm{~K}$ to $403 \mathrm{~K}\left(100{ }^{\circ} \mathrm{C}\right.$ to $\left.130{ }^{\circ} \mathrm{C}\right),{ }^{[6-8]}$ they undergo excessive creep deformation even at moderate stress levels. The poor creep resistance of $\mathrm{Mg}$-Al alloys is generally considered to be associated with the formation of the $\mathrm{Mg}_{17} \mathrm{Al}_{12}$ phase that has poor thermal stability at elevated temperatures. ${ }^{[9,10]}$

There have been considerable efforts directed toward improving the creep resistance of $\mathrm{Mg}$-Al alloys and a number of special alloys have therefore been developed. ${ }^{[7,11]}$ These alloys have additional alloying elements that form either high melting point intermetallic compounds with $\mathrm{Al}$ to suppress the formation of $\mathrm{Mg}_{17} \mathrm{Al}_{12}$ (elements such as $\mathrm{Ca}, \mathrm{RE}$, and $\mathrm{Sr}$ ), or high melting point intermetallic compounds with $\mathrm{Mg}$ (elements including $\mathrm{RE}, \mathrm{Si}$, and $\mathrm{Sn}$ ), or strengthening precipitates (elements such as $\mathrm{Ca}$ and $\mathrm{Nd}$ ).

The primary aim of this study to evaluate the tensile properties and creep resistance of $\mathrm{Mg}$ die-casting alloys developed for elevated temperature applications. For the purpose of comparison, two conventional Mg diecasting alloys, i.e., AZ91 and AM60, and the Al diecasting alloy A380 that is currently used in automotive 
engine blocks, were also evaluated. To better understand the mechanical properties, microstructural features - such as the type and fraction of intermetallic phases, and morphology of the eutectic and supersaturation of $\mathrm{Al}$ in $\alpha-\mathrm{Mg}$-were examined for the selected $\mathrm{Mg}$ die-casting alloys.

\section{MAGNESIUM DIE-CASTING ALLOYS FOR ELEVATED TEMPERATURE APPLICATIONS}

Depending on the creep resistance enhancing elements added, the $\mathrm{Mg}$ die-casting alloys developed so far can be categorized into the following systems: (1) Mg-Al-Si (AS) (2) Mg-Al-Sr (AJ), (3) Mg-Al-Ca (AX), (4) Mg-AlRE (AE), and (5) Mg-RE.

\section{A. Mg-Al-Si Alloys}

The Mg-Al-Si system is attractive because of its low cost and displays good creep resistance at temperatures up to $423 \mathrm{~K}\left(150^{\circ} \mathrm{C}\right)$. The improvement in creep resistance comes from the introduction of the high melting point $\mathrm{Mg}_{2} \mathrm{Si}$ phase. The most common alloys in this family are AS41 (Mg-4A1-1Si) and AS21 (Mg-2Al1Si). AS41 was used by Volkswagen in the 1970s for the crankcase of the Beetle. ${ }^{[12]}$ AS41 has better castability due to the higher Al content, while AS21 has better creep resistance but lower room temperature strength and poorer castability. ${ }^{[13]} \mathrm{AS} 31(\mathrm{Mg}-3 \mathrm{Al}-1 \mathrm{Si})$ is an alloy that has increased in usage recently, with a balance of elevated temperature creep resistance, room temperature mechanical properties, and castability. ${ }^{[14]}$

\section{B. Mg-Al-Sr Alloys}

$\mathrm{Sr}$, like another alkali earth element $\mathrm{Ca}$, is effective in improving the high temperature strength and creep resistance of $\mathrm{Mg}$-Al-based alloys, and creep-resistant alloys based on the Mg-Al-Sr system have been developed, notably AJ52 (Mg-5Al-2Sr) and AJ62 (Mg-6Al$2 \mathrm{Sr}) .{ }^{[15,16]}$ According to the work reported, AJ52 shows higher creep resistance than AJ62 while AJ62 gives a good combination of creep performance and castability. AJ62 has been used in hybrid engine blocks of BMW six-cylinder engines. ${ }^{[9]}$

\section{Mg-Al-Ca Alloys}

There are a range of alloys developed from the $\mathrm{Mg}$ Al-Ca system. ${ }^{[17]}$ It has been known for a long time that $\mathrm{Ca}$ improves the creep resistance of $\mathrm{Mg}-\mathrm{Al}$ alloys. ${ }^{[18]} \mathrm{Ca}$ was also considered to increase the hot tearing susceptibility; however, alloys with high Ca contents have been found to display significantly reduced hot tear susceptibility. ${ }^{[19,20]}$ Most common alloys include MRI153A (Mg-9Al-1Ca-0.1Sr), MRI153M (Mg-8Al-1Ca-0.3Sr), MRI230D (Mg-6.5Al-2Ca-1Sn-0.3Sr), and AXJ530 (Mg-5Al-3Ca-0.2Sr). The MRI series of alloys were developed by Dead Sea Magnesium and Volkswagen AG for various components in automobiles. MRI153A can be regarded as a modified version of AZ91, but it is reported to have better properties such as yield strength, creep resistance, castability, and corrosion performance than AZ91. ${ }^{[21]}$ MRI153M is a beryllium-free, low cost, creep-resistant alloy with the capability of long-term operation at temperatures up to $423 \mathrm{~K}\left(150{ }^{\circ} \mathrm{C}\right)$ under high loads. ${ }^{[22]}$ MRI230D is a die-casting alloy that was developed to address the powertrain applications of the automotive industry, such as engine blocks operating at temperatures up to $463 \mathrm{~K}\left(190^{\circ} \mathrm{C}\right)$ and has very good creep properties. ${ }^{[23]}$ AXJ530, which was developed by General Motors for engine blocks and transmissions, is reported to have at least 40 pct greater tensile and 25 pct greater compressive creep resistance than AE42, ${ }^{[17]}$ and corrosion resistance as good as AZ91D [19] and these properties have been shown to improve further with heat treatment. ${ }^{[24]}$

\section{Mg-Al-RE Alloys}

There are two important alloys in the Mg-Al-RE family, one is AE42 (Mg-4Al-2RE) and the other AE44 (Mg-4Al-4RE). AE42 has been used as a benchmark creep-resistant $\mathrm{Mg}$ die-casting alloy, which exhibits superior creep resistance to AZ91 at temperatures up to $423 \mathrm{~K}\left(150^{\circ} \mathrm{C}\right) .{ }^{[25]}$ However, the creep resistance of AE42 tends to deteriorate rapidly at temperatures above $423 \mathrm{~K}\left(150^{\circ} \mathrm{C}\right)^{[26]}$ and is known to have some issues with hot tearing. ${ }^{[27]}$ Further improvement in creep resistance and castability was achieved by adding more $\mathrm{RE}$, which led to the development of AE44. ${ }^{[28]}$ In these alloys, RE is usually added in the form of misch metal (mixture of various RE elements), with $\mathrm{Ce}$ being the most abundant element, followed by $\mathrm{La}, \mathrm{Nd}$, and $\mathrm{Pr}$. Traditionally, the RE misch metal was produced by direct conversion of the ore without separating individual elements. However, the increased demand for $\mathrm{Nd}$ in magnetic applications in recent years has led to twoelement misch metal (containing only $\mathrm{Ce}$ and La) becoming considerably cheaper than the four-element version. Therefore, besides the conventional four-element AE44 (referred as AE44-4), a cheaper version containing only $\mathrm{Ce}$ and La (referred as AE44-2) has become available. There have also been considerations of how the different rare earths influence the properties of these alloys, and it is clear that there is some difference between them, ${ }^{[29-31]}$ although more work is required especially with recent improvements to the thermodynamic database in this system. ${ }^{[32]}$

\section{E. Mg-RE-Based Alloys}

Since the formation of $\mathrm{Mg}_{17} \mathrm{Al}_{12}$ phase is responsible for the poor creep resistance of $\mathrm{Mg}-\mathrm{Al}$ alloys, there have been efforts in developing Al-free Mg-RE-based diecasting alloys for elevated temperature applications. MEZ (Mg-2.5RE-0.35Zn) was developed by Magnesium Electron, which has better creep resistance than AE42 within the temperature range of $423 \mathrm{~K}$ to $448 \mathrm{~K}$ $\left(150{ }^{\circ} \mathrm{C}\right.$ to $\left.175^{\circ} \mathrm{C}\right) \cdot{ }^{[33]}$ However, the MEZ alloy has very low ductility (1 to 2 pct) and low tensile yield strength (95 to $110 \mathrm{MPa}$ ) at room temperature. ${ }^{[34]}$ Other limitations of $\mathrm{MEZ}$ relate to castability, molten metal 
handling problems, and a relatively high cost. Previous work by some of the authors has indicated that the choice of RE elements does have significant influence on the tensile properties and creep resistance of die-cast Mg-RE alloys. ${ }^{[35,36]}$ By optimizing the RE composition, a new Mg-RE-based die-casting alloy, AM-HP2 +, has been developed, which exhibits excellent creep resistance at temperatures in the range $423 \mathrm{~K}$ to $473 \mathrm{~K}\left(150{ }^{\circ} \mathrm{C}\right.$ to $\left.200^{\circ} \mathrm{C}\right) .^{[37]}$

\section{EXPERIMENTAL METHODS}

In the present study, the following $\mathrm{Mg}$ die-casting alloys developed for elevated applications were selected for evaluation: AS31, AJ52,* MRI153A, MRI153M,

\footnotetext{
*AJ62 was the aim but the measured $\mathrm{Al}$ content in the alloy was closer to AJ52.
}

MRI230D, AE42, AE44-2, AE44-4, and AM-HP2+. For the purpose of comparison, conventional $\mathrm{Mg}$ diecasting alloys AZ91 and AM60, and an Al die-casting alloy A380, which is currently used in engine blocks, were also tested. The analyzed compositions of the selected $\mathrm{Mg}$ alloys are shown in Table I. The alloys were cast using a 250 tonnes Toshiba cold chamber high pressure die-casting machine to produce cylindrical tensile bars with a gage diameter of $5.6 \mathrm{~mm}$. Details of the casting process can be found elsewhere. ${ }^{[37]}$

For microstructural examinations, the samples were prepared by conventional metallographic procedures, which included grinding to a 2400 grit $\mathrm{SiC}$ finish and polishing using a $0.05 \mu \mathrm{m}$ silica suspension. The samples were then examined in a JEOL JSM $7001 \mathrm{~F}$ fieldemission scanning electron microscope (SEM), equipped with a Bruker Quantax energy dispersive X-ray (EDX) spectroscopy system. For comparison purposes, the microstructural examinations were carried out in the half-radius region of the metallographic samples for all $\mathrm{Mg}$ die-casting alloys.
Tensile tests were carried out at room temperature, $423 \mathrm{~K}$ and $448 \mathrm{~K}\left(150{ }^{\circ} \mathrm{C}\right.$ and $\left.175^{\circ} \mathrm{C}\right)$ on a screw-driven Instron machine with a $100 \mathrm{kN}$ load cell. A cross-head speed of $5 \mathrm{~mm} /$ minute and an extensometer with $25 \mathrm{~mm}$ gage length were used. Four repeats were performed per alloy during the tensile testing.

Creep tests were carried out at $423 \mathrm{~K}$ and $448 \mathrm{~K}$ $\left(150{ }^{\circ} \mathrm{C}\right.$ and $\left.175^{\circ} \mathrm{C}\right)$ under a range of stresses. Most creep tests were stopped after 100 hours while some tests were run until specimen failure or reaching 600 hours testing (whichever occurred first). For each creep test condition, two specimens were always loaded to ensure reproducibility and the higher creep strain obtained was used in the analysis and comparison.

\section{RESULTS}

\section{A. Microstructure}

A comparison of microstructures in the selected alloys is shown in Figure 1. The microstructures are characterized basically by primary $\alpha-\mathrm{Mg}$ dendrites surrounded by eutectic containing intermetallic phase in the interdendritic regions. Depending on the alloying additions, several types of different intermetallic phases are formed in these alloys.

For AZ91 and AM60, the intermetallic phase is mainly $\mathrm{Mg}_{17} \mathrm{Al}_{12}$. There appears to be a 'halo' surrounding the $\mathrm{Mg}_{17} \mathrm{Al}_{12}$ phase within the microstructure, which is a characteristic feature of the eutectic $\alpha-\mathrm{Mg}$ after etching. ${ }^{[6,38]}$ The eutectic $\alpha$-Mg solidifies last with the $\mathrm{Mg}_{17} \mathrm{Al}_{12}$ phase during solidification and is usually richer in $\mathrm{Al}$ than the primary $\alpha-\mathrm{Mg}$ grains. It is worth noting that the eutectic is fully divorced, and therefore the $\mathrm{Mg}_{17} \mathrm{Al}_{12}$ phase appears as discrete particles surrounded by a pool of supersaturated eutectic $\alpha-\mathrm{Mg}$. A fully divorced eutectic structure is formed as a result of the high cooling rates experienced in high pressure diecasting in $\mathrm{Mg}-\mathrm{Al}$ alloys rather than the partially divorced structure observed at lower cooling rates. ${ }^{[39]}$

The addition of Si leads to the formation of the $\mathrm{Mg}_{2} \mathrm{Si}$ phase, with a Chinese script morphology in AS31.

Table I. Chemical Compositions (Weight Percent) of the Mg Die-Casting Alloys in This Study (Analyzed by Inductively Coupled Plasma-Optical Emission Spectroscopy)

\begin{tabular}{|c|c|c|c|c|c|c|c|c|c|c|c|c|}
\hline Alloy & $\mathrm{Al}$ & $\mathrm{Si}$ & $\mathrm{Ca}$ & $\mathrm{Sr}$ & $\mathrm{Sn}$ & $\mathrm{Mn}$ & $\mathrm{Zn}$ & $\mathrm{Ce}$ & $\mathrm{La}$ & $\mathrm{Nd}$ & $\operatorname{Pr}$ & $\mathrm{Y}$ \\
\hline AZ91 & 8.88 & - & - & - & - & 0.19 & 0.74 & - & - & - & - & - \\
\hline AM60 & 6.26 & - & - & - & - & 0.29 & 0.1 & - & - & - & - & - \\
\hline AS31 & 3.55 & 0.59 & - & - & - & 0.28 & - & - & - & - & - & - \\
\hline AJ52 & 5.2 & - & 0.07 & 1.86 & - & $0.25^{*}$ & - & - & - & - & - & - \\
\hline MRI153A & 8.31 & - & 1.01 & 0.09 & $<0.01$ & 0.22 & 0.75 & - & - & - & - & - \\
\hline MRI153M & 7.73 & - & 1.06 & 0.30 & $<0.01$ & 0.25 & $<0.01$ & - & - & - & - & - \\
\hline MRI230D & 6.49 & - & 2.00 & 0.43 & 0.95 & 0.28 & $<0.01$ & - & - & - & - & - \\
\hline AXJ530 & 4.46 & - & 3.33 & 0.17 & - & $0.25^{*}$ & - & - & - & - & - & - \\
\hline $\mathrm{AE} 42$ & 3.45 & - & - & - & - & 0.31 & - & 1.45 & 0.60 & 0.41 & 0.1 & - \\
\hline AE44-2 & 3.95 & - & - & - & - & 0.15 & - & 2.82 & 1.32 & - & - & - \\
\hline AE44-4 & 3.73 & - & - & - & - & 0.30 & - & 2.47 & 1.21 & 0.51 & $0.1 *$ & - \\
\hline $\mathrm{AM}-\mathrm{HP} 2+$ & - & - & - & - & - & - & 0.45 & 0.97 & 1.63 & 0.96 & 0.05 & 0.11 \\
\hline
\end{tabular}

Where the amount is not listed the composition is below the detectable range usually $0.01 \mathrm{wt}$ pct.

*Nominal value. 

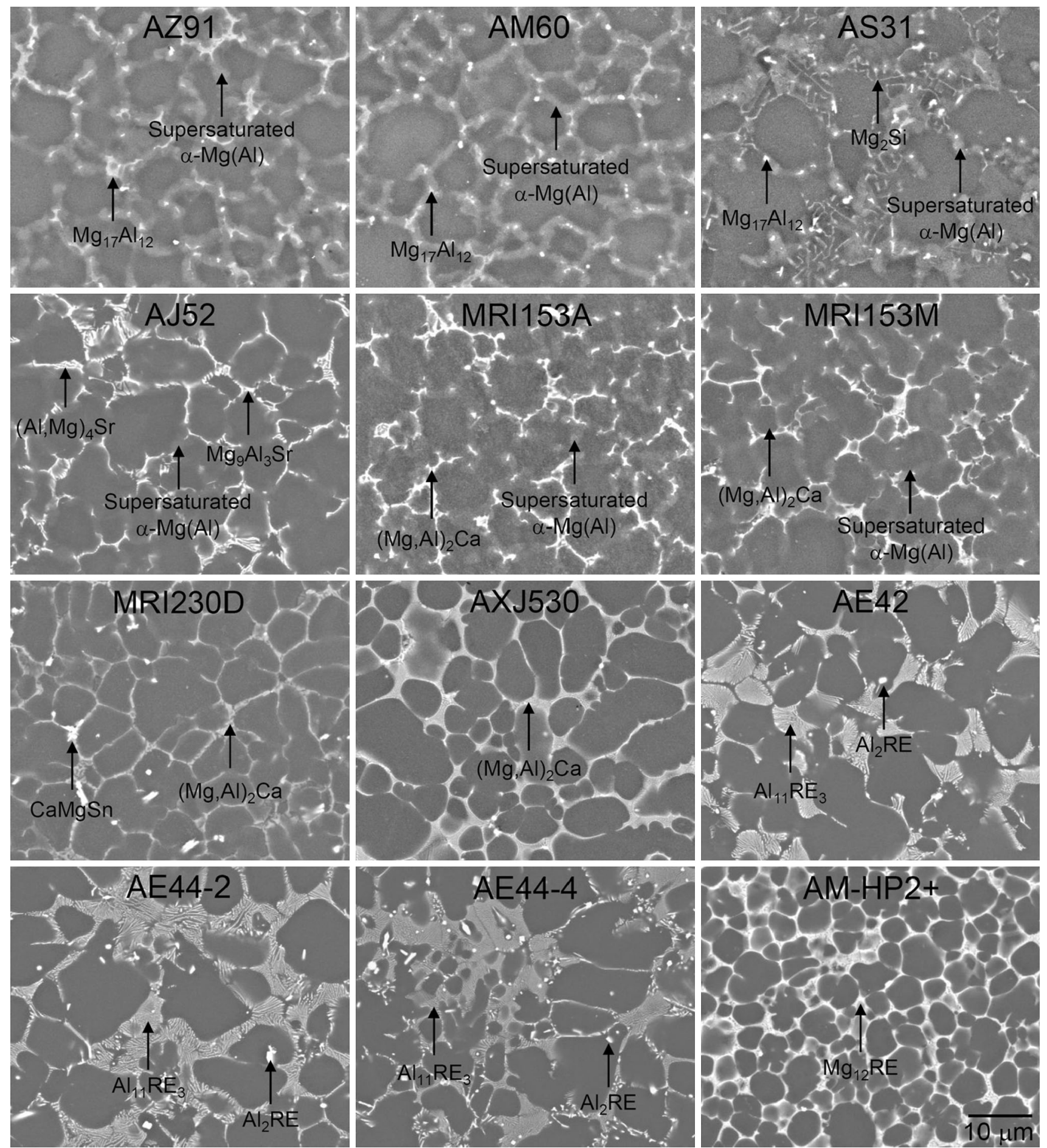

Fig. 1-SEM backscattered electron images showing typical microstructure of the selected $\mathrm{Mg}$ die-casting alloys. Major intermetallic phases are indicated by arrows.

Besides the $\mathrm{Mg}_{2} \mathrm{Si}$ phase, the $\mathrm{Mg}_{17} \mathrm{Al}_{12}$ phase is still present, which is consistent with previous studies. ${ }^{[14,40]}$ The 'halo' feature is also visible, suggesting that there is also a supersaturation of $\mathrm{Al}$ in the eutectic $\alpha-\mathrm{Mg}$.

The $\mathrm{Mg}_{17} \mathrm{Al}_{12}$ phase is difficult to find in $\mathrm{AJ} 52$. Instead, two other intermetallic phases are present in AJ52, i.e., $\mathrm{Al}_{4} \mathrm{Sr}$ and $\mathrm{Mg}_{9} \mathrm{Al}_{3} \mathrm{Sr}$, as reported in the literature. ${ }^{[16,41]}$ The $\mathrm{Al}_{4} \mathrm{Sr}$ phase appears to have a regular eutectic morphology (lamellar), but the $\mathrm{Mg}_{9}$ $\mathrm{Al}_{3} \mathrm{Sr}$ phase has a blocky morphology, indicating that the $\mathrm{Mg}_{9} \mathrm{Al}_{3} \mathrm{Sr}$ phase is fully divorced. There is still a supersaturation of $\mathrm{Al}$ in the eutectic $\alpha-\mathrm{Mg}$.

Similar microstructures are observed in the MRI alloys and $\mathrm{AXJ} 530$, with $(\mathrm{Mg}, \mathrm{Al})_{2} \mathrm{Ca}$ being the major intermetallic phase. Besides the $(\mathrm{Mg}, \mathrm{Al})_{2} \mathrm{Ca}$ phase, a $\mathrm{CaMgSn}$ phase is also present in MRI230D. According 
to a previous study, ${ }^{[17]}$ the $(\mathrm{Mg}, \mathrm{Al})_{2} \mathrm{Ca}$ phase is continuous in general, though this phase sometimes exhibits a lamellar morphology, indicating a partially divorced eutectic structure. The 'halo' feature is visible in MRI153A and MRI153D, but not in MRI230D or AXJ530, indicating that $\mathrm{Al}$ is supersaturated in the $\alpha-\mathrm{Mg}$ for the former alloys but not for the latter alloys, probably due to the higher $\mathrm{Al}$ content in the former alloys.

There are two types of intermetallic phase in the AE alloys, with $\mathrm{Al}_{11} \mathrm{RE}_{3}$ being the major one and $\mathrm{Al}_{2} \mathrm{RE}$ the minor one. While the $\mathrm{Al}_{11} \mathrm{RE}_{3}$ phase has a lamellar morphology the $\mathrm{Al}_{2} \mathrm{RE}$ phase has a particulate shape. There is no strong indication that the eutectic $\alpha-\mathrm{Mg}$ is supersaturated with $\mathrm{Al}$ in these alloys. However, a previous study ${ }^{[42]}$ revealed the presence of a supersaturation of $\mathrm{Al}$ in the $\alpha-\mathrm{Mg}$ in a die-cast $\mathrm{AE} 42$.

For AM-HP2 +, the intermetallic phase is mainly $\mathrm{Mg}_{12} \mathrm{RE}$, with a partially or fully divorced eutectic structure. More details can be found elsewhere. ${ }^{[43]}$

The microstructural features of the above alloys are summarized in Table II.

\section{B. Tensile Properties}

The room temperature tensile properties of the selected alloys are shown in Figure 2. Among the $\mathrm{Mg}$ die-casting alloys investigated, MRI230D, AXJ530, and $\mathrm{AM}-\mathrm{HP} 2+$ have higher yield strength than the Al alloy A380, but the ductility is relatively low in all three alloys, which is close to that in A380. On the other hand, AS31 and the AE series alloys have very good ductility, but the yield strength of these alloys is lower than that of A380. In terms of tensile strength, all $\mathrm{Mg}$ die-casting alloys except AM-HP2 + are very similar. It is noted that A380 has much higher tensile strength than all $\mathrm{Mg}$ die-casting alloys, including MRI230D, AXJ530 and AM-HP2 +, indicating that A380 has a higher work hardening rate than the $\mathrm{Mg}$ die-casting alloys.

The tensile properties of the selected alloys at $423 \mathrm{~K}$ and $448 \mathrm{~K}\left(150^{\circ} \mathrm{C}\right.$ and $\left.175^{\circ} \mathrm{C}\right)$ are shown in Figures 3 and 4 , respectively. Compared with the properties at room temperature, there is a decrease in yield strength for all $\mathrm{Mg}$ die-casting alloys, accompanied by an increase in ductility. However, there seems little difference in yield strength and ductility for A380 at room temperature, $423 \mathrm{~K}$ and $448 \mathrm{~K}\left(150{ }^{\circ} \mathrm{C}\right.$ and $\left.175^{\circ} \mathrm{C}\right)$. Consequently, all $\mathrm{Mg}$ die-casting alloys have lower yield strength but higher ductility than A380 at these temperatures. MRI230D, AXJ530, and AM-HP2 + stand out as the $\mathrm{Mg}$ casting alloys that have a yield strength closest to that of $\mathrm{A} 380$ at $423 \mathrm{~K}$ and $448 \mathrm{~K}\left(150{ }^{\circ} \mathrm{C}\right.$ and $\left.175^{\circ} \mathrm{C}\right)$.

\section{Creep Properties}

A comparison of creep curves of the selected alloys at $423 \mathrm{~K}\left(150{ }^{\circ} \mathrm{C}\right)$ and a relatively high stress level of $90 \mathrm{MPa}$ is shown in Figure 5. This stress level is close to the yield strength for AM60, AS31, AJ52, and AE42, but is lower than the yield strength for the other alloys at $423 \mathrm{~K}\left(150{ }^{\circ} \mathrm{C}\right)$. Under this stress, the specimens of AZ91 and AM60 failed instantaneously (not shown). While AS31, AJ52, and MRI153A failed after about 50, 100 , and 400 hours, respectively, the other alloys survived to 600 hours. Among the Mg die-casting alloys tested, MRI230D, AXJ530, AE44-2, AE44-4, and AM$\mathrm{HP} 2+$ had relatively low creep strains, even lower than that of A380.

Supplementary creep tests were conducted at various stress levels in order to get a more complete picture of creep resistance of these alloys. Figure 6 shows the creep strain values at 100 hours testing as a function of the applied stress at $423 \mathrm{~K}$ and $448 \mathrm{~K}\left(150{ }^{\circ} \mathrm{C}\right.$ and $\left.175^{\circ} \mathrm{C}\right)$. It appears that the creep strain at 100 hours $\left(\varepsilon_{100}\right)$ and the applied stress $(\sigma)$ can be roughly described by the following equation:

$$
\ln \varepsilon_{100}=A \sigma+B,
$$

where $A$ and $B$ are material constants.

From the plots in Figure 6, the 0.1 pct creep strength, which is defined as the stress to produce 0.1 pct creep strain at 100 hours, can be determined and is used to describe the creep resistance of the alloys in this work. Comparisons of the 0.1 pct creep strength for the selected alloys at $423 \mathrm{~K}$ and $448 \mathrm{~K}\left(150{ }^{\circ} \mathrm{C}\right.$ and

Table II. Summary of Microstructural Features in the Selected Mg Die-Casting Alloys

\begin{tabular}{|c|c|c|c|c|}
\hline Alloy & $\begin{array}{c}\text { Major Intermetallic } \\
\text { Phases }\end{array}$ & Morphology of Eutectic & $\begin{array}{l}\text { Volume Fraction of } \\
\text { Intermetallics }(\mathrm{pct})^{*}\end{array}$ & $\begin{array}{l}\text { Supersaturation } \\
\text { of } \mathrm{Al} \text { in } \alpha-\mathrm{Mg}\end{array}$ \\
\hline AZ91 & $\mathrm{Mg}_{17} \mathrm{Al}_{12}$ & fully divorced & 10.2 & high \\
\hline AM60 & $\mathrm{Mg}_{17} \mathrm{Al}_{12}$ & fully divorced & 5.4 & high \\
\hline AS31 & $\mathrm{Mg}_{2} \mathrm{Si}, \mathrm{Mg}_{17} \mathrm{Al}_{12}$ & fully divorced & 5.7 & high \\
\hline AJ52 & $\mathrm{Al}_{4} \mathrm{Sr}, \mathrm{Mg}_{9} \mathrm{Al}_{3} \mathrm{Sr}$ & lamellar $\left(\mathrm{Al}_{4} \mathrm{Sr}\right) /$ fully divorced $\left(\mathrm{Mg}_{9} \mathrm{Al}_{3} \mathrm{Sr}\right)$ & 11.1 & high \\
\hline MRI153A & $(\mathrm{Mg}, \mathrm{Al})_{2} \mathrm{Ca}$ & partially divorced & 12.3 & high \\
\hline MRI153M & $(\mathrm{Mg}, \mathrm{Al})_{2} \mathrm{Ca}$ & partially divorced & 12.1 & high \\
\hline MRI230D & $(\mathrm{Mg}, \mathrm{Al})_{2} \mathrm{Ca}, \mathrm{MgAlSn}$ & partially $\left((\mathrm{Mg}, \mathrm{Al})_{2} \mathrm{Ca}\right) /$ fully divorced $(\mathrm{MgAlSn})$ & 16.2 & low \\
\hline AXJ530 & $(\mathrm{Mg}, \mathrm{Al})_{2} \mathrm{Ca}$ & partially divorced & 16.6 & low \\
\hline AE42 & $\mathrm{Al}_{11} \mathrm{RE}_{3}, \mathrm{Al}_{2} \mathrm{RE}$ & lamellar $\left(\mathrm{Al}_{11} \mathrm{RE}_{3}\right) /$ fully divorced $\left(\mathrm{Al}_{2} \mathrm{RE}\right)$ & 10.3 & low \\
\hline AE44-2 & $\mathrm{Al}_{11} \mathrm{RE}_{3}, \mathrm{Al}_{2} \mathrm{RE}$ & lamellar $\left(\mathrm{Al}_{11} \mathrm{RE}_{3}\right) /$ fully divorced $\left(\mathrm{Al}_{2} \mathrm{RE}\right)$ & 15.2 & no \\
\hline AE44-4 & $\mathrm{Al}_{11} \mathrm{RE}_{3}, \mathrm{Al}_{2} \mathrm{RE}$ & lamellar $\left(\mathrm{Al}_{11} \mathrm{RE}_{3}\right) /$ fully divorced $\left(\mathrm{Al}_{2} \mathrm{RE}\right)$ & 12.6 & no \\
\hline $\mathrm{AM}-\mathrm{HP} 2+$ & $\mathrm{Mg}_{12} \mathrm{RE}$ & fibrous/lamellar (continuous intermetallic) & 14.4 & no \\
\hline
\end{tabular}

*Determined from the SEM backscattered electron images as shown in Fig. 1. 


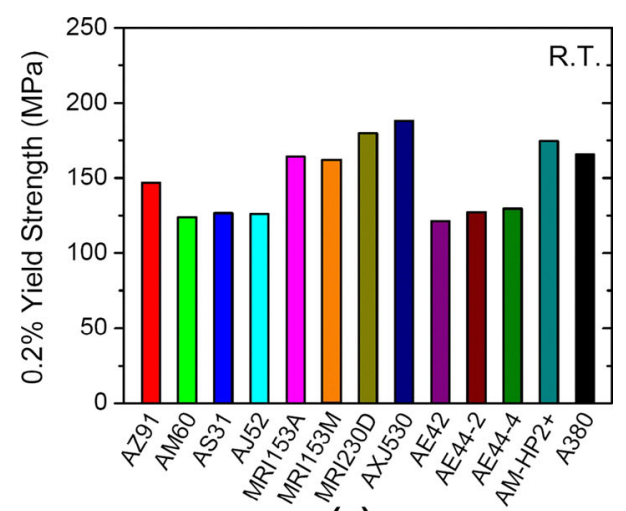

(a)

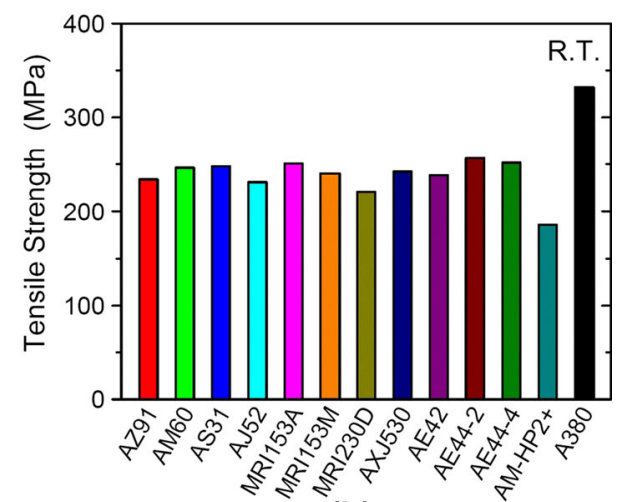

(b)

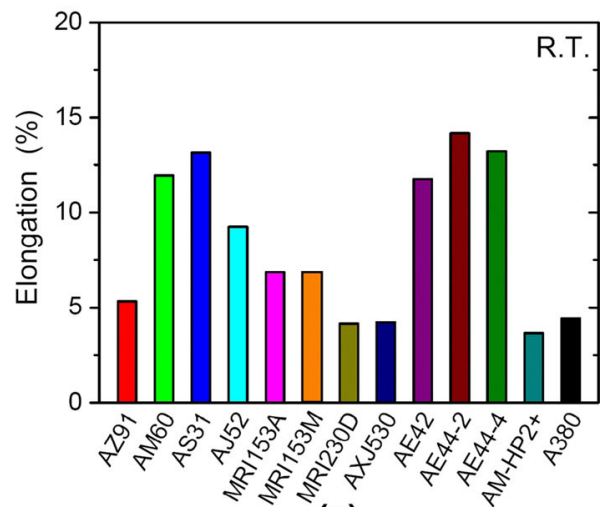

(c)

Fig. 2-Tensile properties of the selected $\mathrm{Mg}$ die-casting alloys at room temperature: (a) 0.2 pct yield strength, $(b)$ ultimate tensile strength and (c) elongation. Al die-casting alloy A380 is included for comparison.

$175^{\circ} \mathrm{C}$ ) are shown in Figure 7. The order (best to worst) of creep resistance at $150{ }^{\circ} \mathrm{C}$ for the $\mathrm{Mg}$ die-casting alloys appears to be: MRI230D $>$ AM-HP2 $+>$ AXJ $530>$ AE44-4 $>$ AE44-2 > AE42 > MRI153M > AJ52 > MRI153A $>$ AS31 $>$ AM60 $>$ AZ91. For creep resistance at $448 \mathrm{~K}\left(175{ }^{\circ} \mathrm{C}\right)$, the order appears to be AM-HP2 + > AXJ530 > MRI230D > AE44-4 > AE44$2>$ AE42 > MRI153M > AJ52 > MRI153A > AS31. Among the Mg die-casting alloys, MRI230D, AXJ530, AE44-2, AE44-4, and AM-HP2 + have better 0.1 pct creep strength than A380 at both temperatures.

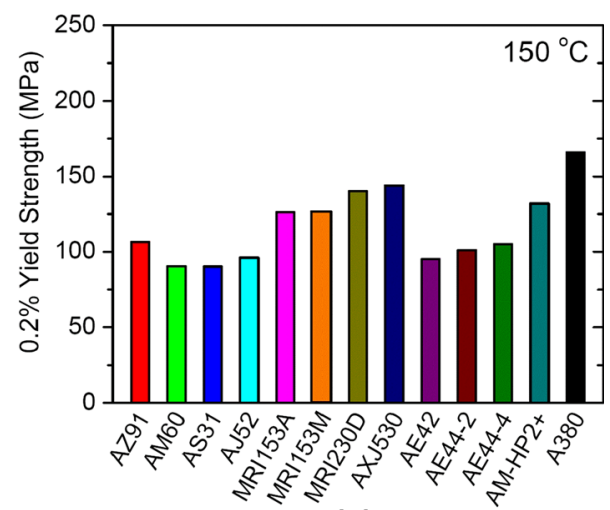

(a)

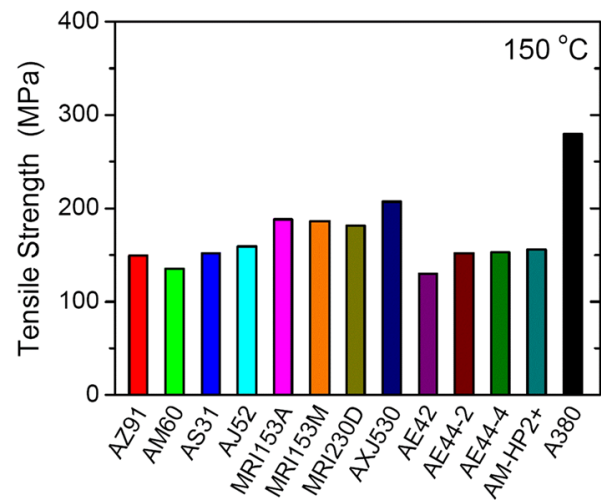

(b)

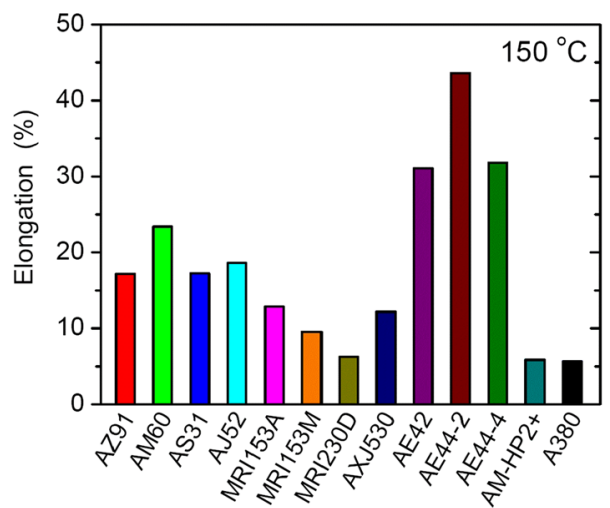

(c)

Fig. 3-Tensile properties of the selected $\mathrm{Mg}$ die-casting alloys at $423 \mathrm{~K}\left(150^{\circ} \mathrm{C}\right)$ : (a) 0.2 pct yield strength, $(b)$ ultimate tensile strength and (c) elongation. Al die-casting alloy A380 is included for comparison.

\section{DISCUSSION}

\section{A. Microstructure/Tensile Properties Relationship}

Given that the microstructure of $\mathrm{Mg}$ die-casting alloys is comprised typically of primary $\alpha-\mathrm{Mg}$ dendrites surrounded by the intermetallic phase containing eutectic in the interdendritic/grain boundary regions, it has been suggested that such $\mathrm{Mg}$ die-casting alloys can be treated as in situ composites with soft regions (primary $\alpha-\mathrm{Mg}$ ) and hard regions (dispersed and/or interconnected intermetallic phases). ${ }^{[44,45]}$ It is well established that 


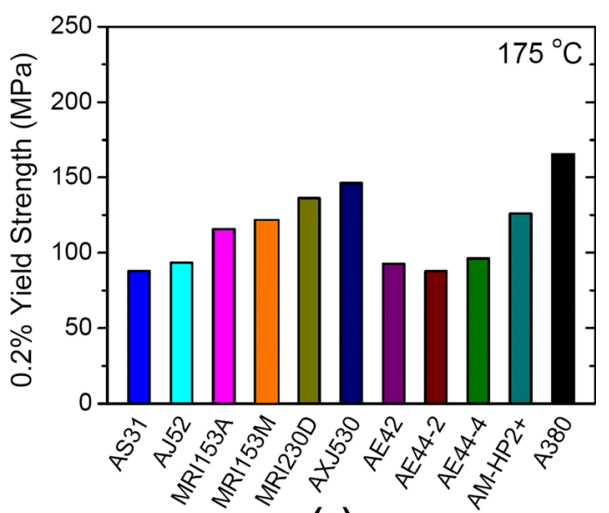

(a)

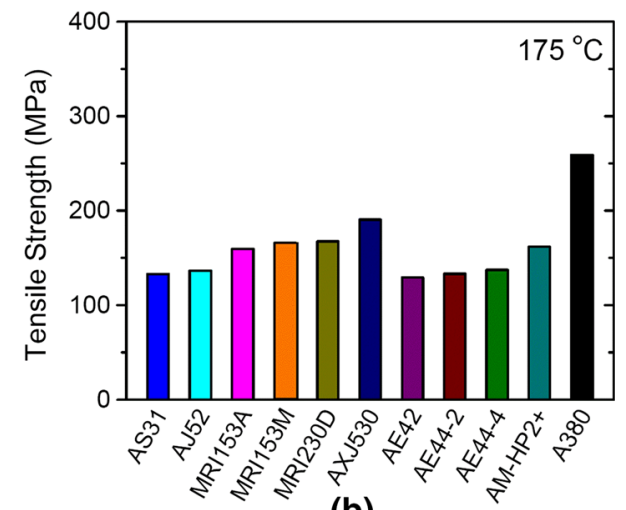

(b)

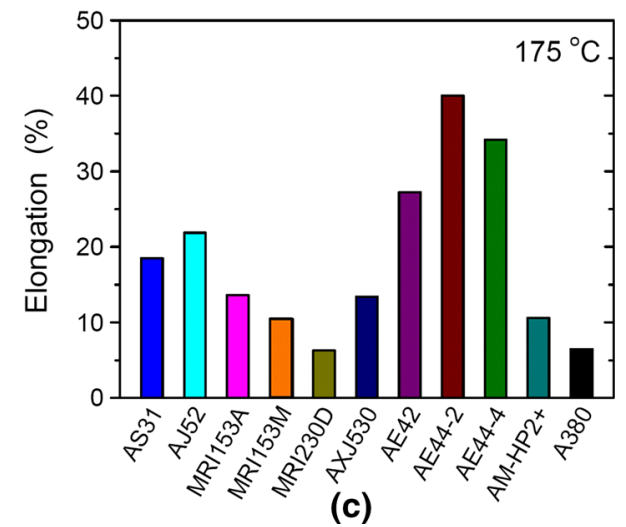

Fig. 4-Tensile properties of the selected $\mathrm{Mg}$ die-casting alloys at $448 \mathrm{~K}\left(175^{\circ} \mathrm{C}\right)$ : (a) $0.2 \mathrm{pct}$ yield strength, (b) ultimate tensile strength and $(c)$ elongation. Al die-casting alloy A380 is included for comparison.

second phases in ductile materials are known to increase strength for which the theory is well established. ${ }^{[46-48]}$ In alloys containing a ductile primary phase, the strain hardening is related to the volume fraction and modulus of the dispersed particles for strains lower than 1 pet. ${ }^{[47]}$ The role of intermetallic phases in strengthening has been verified in die-cast $\mathrm{Mg}^{-\mathrm{Al}^{[49,50]}}$ and $\mathrm{Mg}-\mathrm{RE}^{[36]}$ binary alloys, in which the yield strength showed a monotonic increase with increasing content of the alloying element. Furthermore, a good correlation between the yield strength and the amount of intermetallic phase was observed in binary Mg-RE alloys. ${ }^{[36]}$ For verification purposes, an effort is made to correlate

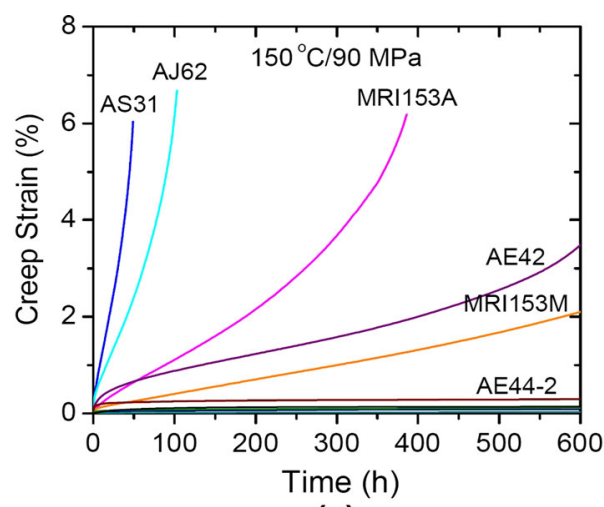

(a)

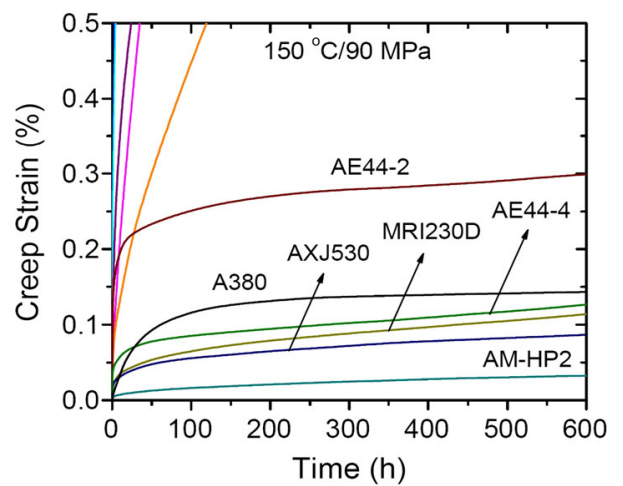

(b)

Fig. 5-Creep curves of the selected Mg die-casting alloys at $423 \mathrm{~K}$ $\left(150{ }^{\circ} \mathrm{C}\right)$ under a stress of $90 \mathrm{MPa}$. (b) Shows an enlarged portion of (a). $\mathrm{Al}$ die-casting alloy $\mathrm{A} 380$ is included for comparison.

the tensile properties with the fraction of intermetallic phases for the selected $\mathrm{Mg}$ die-casting alloys in this work.

The correlation between the yield strength and the fraction of intermetallic phases for the selected $\mathrm{Mg}$ diecasting alloys at room temperature and elevated temperatures is shown in Figure 8. There appears to be a good correlation between the yield strength and the amount of intermetallic phases for most alloys (except AJ52 and the AE alloys), not only at room temperature but also at elevated temperatures, suggesting that the amount of intermetallic phase is an important factor for the yield strength of $\mathrm{Mg}$ die-casting alloys, as has been observed previously. ${ }^{[36]}$ Since the intermetallic phases are different in some of these alloys, it seems that the type of intermetallic phase may not be as important in determining yield strength of $\mathrm{Mg}$ die-casting alloys as the amount of the intermetallic phase. It is noted that AJ52 and the AE alloys are exceptions, with the measured yield strength being much lower than that expected from the contribution of the intermetallic phase. Since the major intermetallic phases in AJ52 and the AE alloys tend to have a lamellar structure, it is likely that the morphology of the intermetallic phase also plays a role in influencing the alloy strength, i.e., the strengthening contribution is higher when the intermetallic phase is divorced and continuous rather than being lamellar. This difference can be explained by the additional strengthening effect from the percolating 


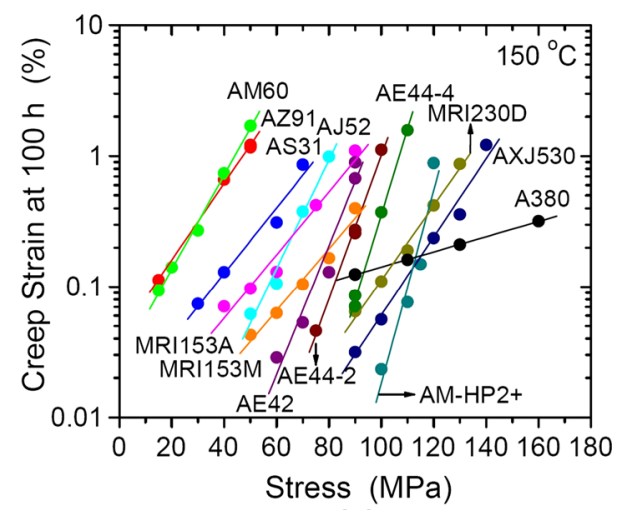

(a)

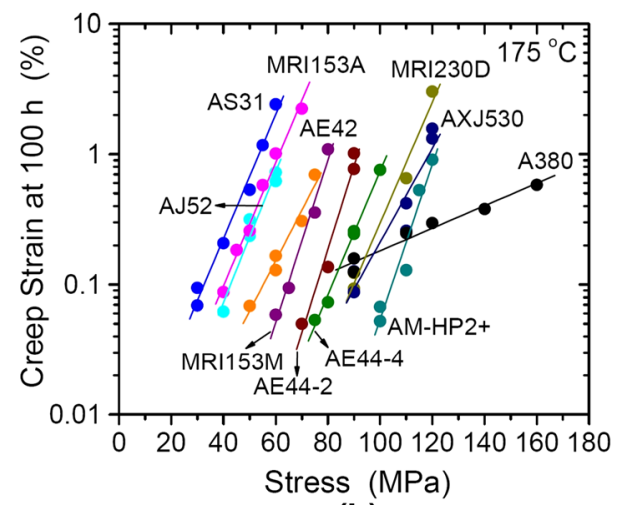

(b)

Fig. 6- Creep strain at 100 hours as a function of the applied stress for the selected $\mathrm{Mg}$ die-casting alloys at $(a) 423 \mathrm{~K}\left(150^{\circ} \mathrm{C}\right)$ and $(b)$ $448 \mathrm{~K}\left(175^{\circ} \mathrm{C}\right)$. Al die-casting alloy A380 is included for comparison.

network of the intermetallic phase, which was proposed recently by Zhang et al. ${ }^{[51,52]}$ Based on dual-beam focused-ion beam (FIB) tomography and finite element analysis (FEA), Zhang et al. ${ }^{[51,52]}$ provided detailed insight into the 3D configuration and deformation behavior of the percolating intermetallic phases in diecast $\mathrm{Mg}-\mathrm{Al}$ and $\mathrm{Mg}-\mathrm{RE}$ alloys. They found that the intermetallic phases with profuse spatial interconnection have a higher strengthening effect than what would be expected through dispersion hardening, i.e., isolated particles with the same volume fraction. For the alloys with a divorced eutectic structure and continuous intermetallic in the present study, i.e., AZ91, AM60, AS31, the MRI series, AXJ530, and AM-HP2+, the intermetallic phases tend to percolate into a continuous network, which leads to additional strengthening.

The correlation between the tensile ductility and the fraction of intermetallic phases for the selected $\mathrm{Mg}$ diecasting alloys at room temperature and elevated temperatures is shown in Figure 9. Again excluding AJ52 and the AE alloys, there appears a trend that the ductility decreases with increasing fraction of intermetallic phases for the other $\mathrm{Mg}$ alloys at both room and elevated temperatures though the data points are relatively scattered. This trend is opposite to that for the correlation between the yield strength and the fraction of intermetallic phases. As expected, higher ductility is observed in AJ52 and the AE alloys as compared with

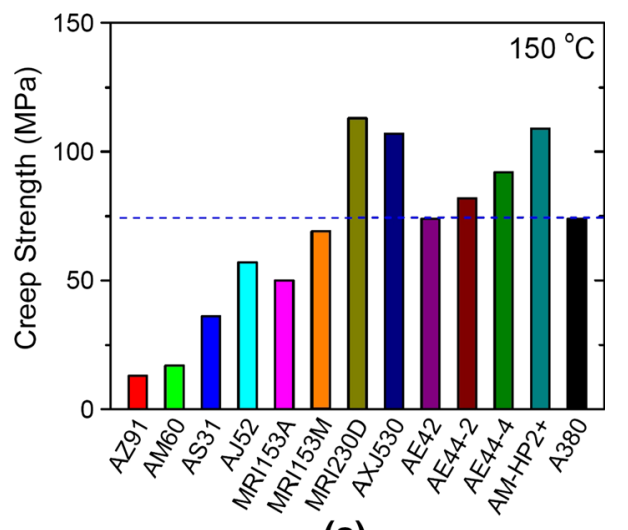

(a)

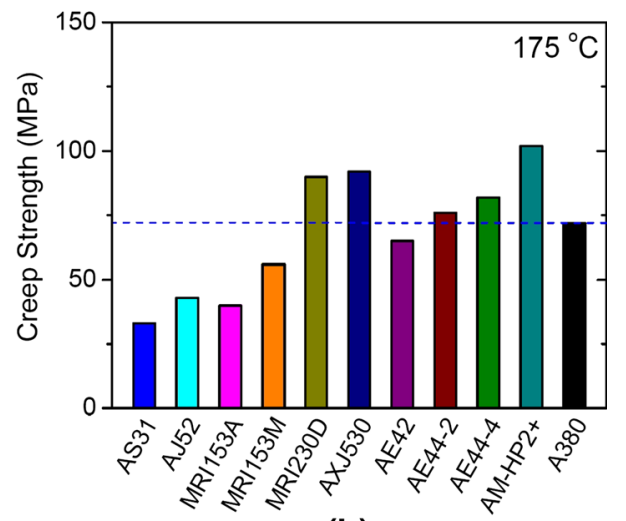

(b)

Fig. 7-Creep strength, defined as the stress to produce 0.1 pct creep strain at $100 \mathrm{~h}$, for the selected $\mathrm{Mg}$ die-casting alloys at $(a) 423 \mathrm{~K}$ $\left(150{ }^{\circ} \mathrm{C}\right)$ and $(b) 448 \mathrm{~K}\left(175^{\circ} \mathrm{C}\right)$. Al die-casting alloy A380 is included for comparison.

the other alloys with a similar fraction of intermetallic phases, indicating that the ductility is not only affected by the amount of intermetallic phase but also by its morphology. Higher ductility is favored when the intermetallic phase has a lamellar structure instead of being fully divorced, probably due to a better compliance between the intermetallic phase and the surrounding matrix. ${ }^{[53]}$

It should be pointed out that grain size strengthening and solid solution strengthening are not taken into account in the above analysis. The contributions of grain size strengthening are considered to be similar in these $\mathrm{Mg}$ alloys since there appears to be no significant difference in grain size. However, there are significant variations in the degree of supersaturation of solutes among the selected alloys. Obvious supersaturation of Al solute is seen in AZ91, AM60, AS31, AJ52, MRI153A, and MRI153M (Figure 1). In addition, there is some degree of superstation of solutes in MRI230D, AXJ530, AE42, and AM-HP2 + as well, which is inferred from the precipitation of fine particles, i.e., $\mathrm{Al}_{2} \mathrm{Ca}$ for MRI230D ${ }^{[23]}$ and AXJ530, ${ }^{[24]} \mathrm{Mg}_{17} \mathrm{Al}_{12}$ for AE42, ${ }^{[42]}$ and $\mathrm{Mg}_{3} \mathrm{Nd}$ for AM-HP2 $+{ }^{[43]}$ either after creep or artificial aging at elevated temperatures. On the other hand, there is probably no supersaturation of solute in AE44-2 and AE44-4, evidenced by the absence of precipitation in the $\mathrm{Mg}$ matrix after high temperature 


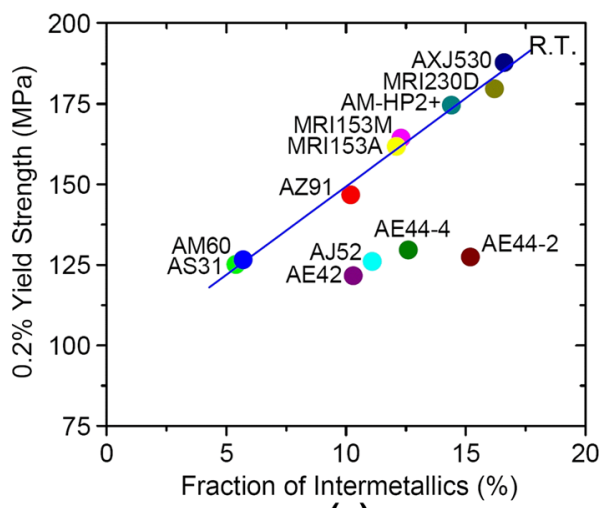

(a)

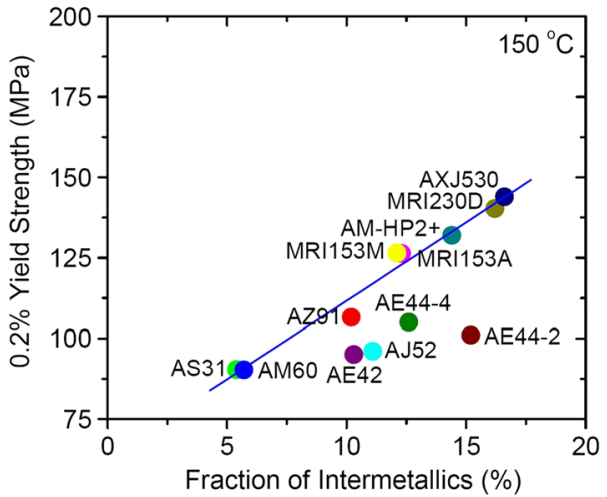

(b)

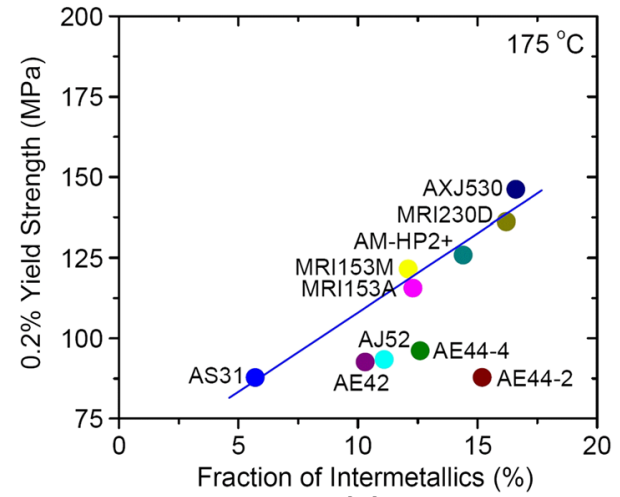

(c)

Fig. 8 - Correlation of 0.2 pct yield strength at (a) room temperature, $(b) 423 \mathrm{~K}\left(150{ }^{\circ} \mathrm{C}\right)$ and $(c) 448 \mathrm{~K}\left(175^{\circ} \mathrm{C}\right)$ with fraction of intermetallic phases for the selected $\mathrm{Mg}$ die-casting alloys. The fraction of intermetallic phases was determined from the SEM backscattered electron images as shown in Fig. 1.

creep tests. ${ }^{[54]}$ Thus, strengthening by supersaturated solutes is likely to be another factor that may account for the observed differences in yield strength in the selected $\mathrm{Mg}$ die-casting alloys. However, a recent study ${ }^{[55]}$ showed that the contribution of solute strengthening is relatively small compared with other strengthening mechanisms for $\mathrm{Mg}$ die-casting alloys.

\section{B. Microstructure/Creep Resistance Relationship}

It has long been accepted that grain boundary sliding makes a major contribution to creep deformation of $\mathrm{Mg}$

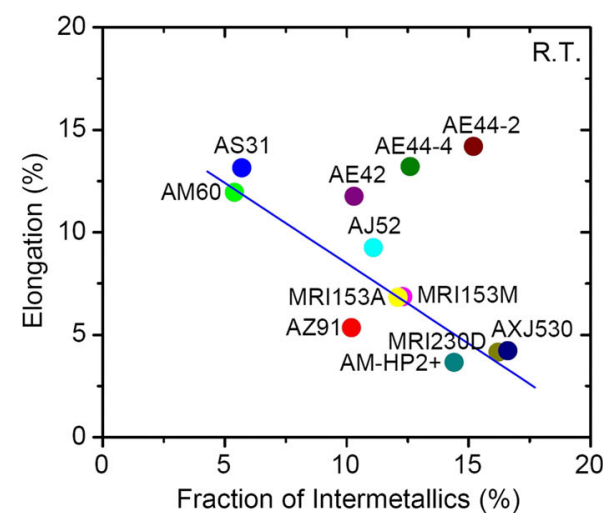

(a)

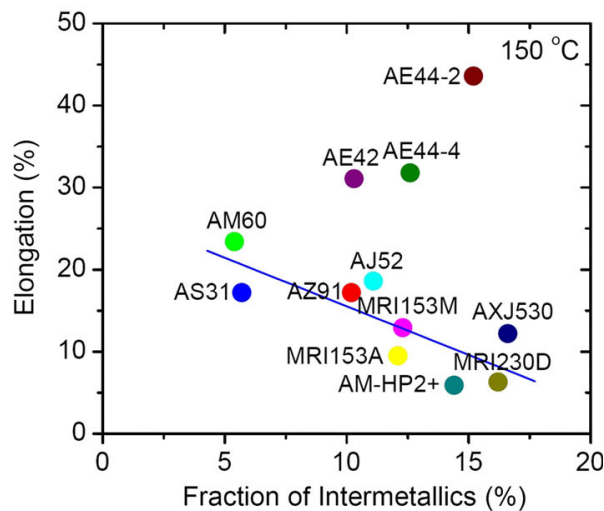

(b)

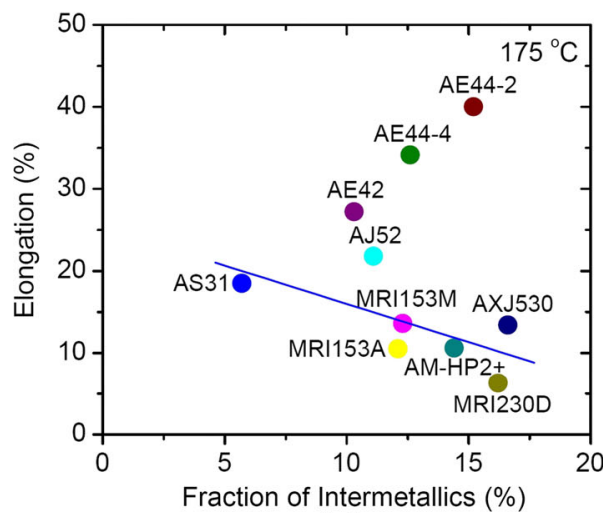

(c)

Fig. 9-Correlation of tensile elongation at $(a)$ room temperature, (b) $423 \mathrm{~K}\left(150^{\circ} \mathrm{C}\right)$ and $(c) 448 \mathrm{~K}\left(175^{\circ} \mathrm{C}\right)$ with fraction of intermetallic phases for the selected $\mathrm{Mg}$ die-casting alloys. The fraction of intermetallic phases was determined from the SEM backscattered electron images as shown in Fig. 1.

alloys. ${ }^{[8,56-59]}$ According to Bell and Langdon, ${ }^{[58]}$ the contribution of grain boundary sliding to creep deformation can be as high as 80 pet for a $\mathrm{Mg}-0.78 \mathrm{Al}$ alloy. As a result, the introduction of thermally stable intermetallic particles to inhibit grain boundary sliding has been the guiding alloy design principle in developing creep-resistant $\mathrm{Mg}$ alloys. ${ }^{[5,11]}$ Furthermore, a recent study ${ }^{[59]}$ suggested that a highly interconnected and strong skeleton of intermetallic phase is able to effectively shield load from the softer $\alpha-\mathrm{Mg}$ matrix and therefore alloys with a higher interconnectivity of 
intermetallic phase should have higher creep resistance than those with a lower interconnectivity. However, there are increasingly more studies ${ }^{[23,24,35,60,61]}$ showing that intra-granular strengthening by solutes/precipitates also has a great influence on the creep resistance of $\mathrm{Mg}$ alloys. For example, Maruyama et al. ${ }^{[60]}$ reported that $\mathrm{Y}$ has a more significant effect in improving the creep resistance of $\mathrm{Mg}$ alloys than $\mathrm{Al}$, which is largely due to a higher solid solution strengthening effect. Suzuki et $a{ }^{[24]}$ studied the precipitation strengthening effect of $\mathrm{Al}_{2} \mathrm{Ca}$ in a die-cast AXJ530 alloy and reported that the creep resistance was improved by a factor of 1.5 to 2 after a peak aging treatment [1 hours at $523 \mathrm{~K}$ $\left.\left(250{ }^{\circ} \mathrm{C}\right)\right]$. More recently, Zhu et al. ${ }^{[35]}$ examined the microstructure and creep resistance of die-cast $\mathrm{Mg}$-RE $(\mathrm{RE}=\mathrm{La}, \mathrm{Ce}$ or $\mathrm{Nd})$ binary alloys with various $\mathrm{RE}$ contents in an effort to separate the relative contributions from grain boundary reinforcement by intermetallic phases and intra-granular strengthening by solutes/ precipitates. They considered that intra-granular strengthening by solutes/precipitates is more important than grain boundary reinforcement by intermetallic phases to creep resistance of high pressure die-cast $\mathrm{Mg}$ alloys with a significant amount of intermetallic as is the case in all alloys in the present work.

To reveal the role of intermetallic phase in creep resistance, correlations are made between the 0.1 pct creep strength and the fraction of intermetallic phases for the selected $\mathrm{Mg}$ die-casting alloys (Figure 10). Different to that for the correlations of the yield strength observed in Figure 8, AJ52 and AE alloys are no longer separated from the other alloys in the correlations of the creep strength. This suggests that the percolation of intermetallic phase may not be as important to creep resistance as it is to yield strength. Although there appears a general trend showing that the creep resistance may increase with increasing fraction of intermetallic phases, significant variations in creep resistance are seen for alloys with a similar fraction of intermetallic phases. For example, MRI230D, AXJ530, and AM-HP2 + have a similar fraction of intermetallic phases to AE44-2, but the creep resistance is much better in the former alloys than the latter. This difference in creep resistance is considered to be related to the higher levels of solute in MRI230D, AXJ530, and AMHP2 + alloys as compared to AE44-2. However, this is not the case for other alloys with similar fractions of intermetallic phases, such as AZ91 and AE42. The yield strength of AZ91 is higher than that of AE42 even at $423 \mathrm{~K}\left(150^{\circ} \mathrm{C}\right)$, but AZ91 has significantly lower creep resistance than AE42. This inconsistency regarding the influence of supersaturated solute on creep resistance can be related to the diffusivity of the solute and the thermal stability of the precipitates that form during creep. The precipitation process probably occurs dynamically because dislocations produced by creep deformation can act as heterogeneous nucleation sites. The precipitation normally leads to hardening if the concurrent loss of solid solution strengthening is compensated accordingly. However, the precipitation strengthening will not persist if the precipitate phase is not thermally stable and coarsens rapidly during the prolonged creep

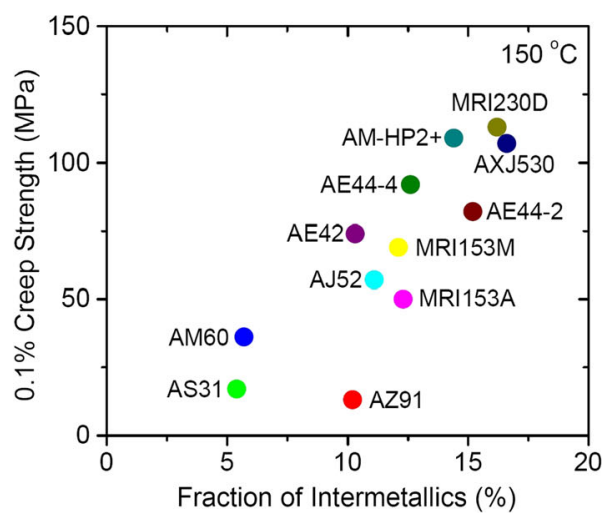

(a)

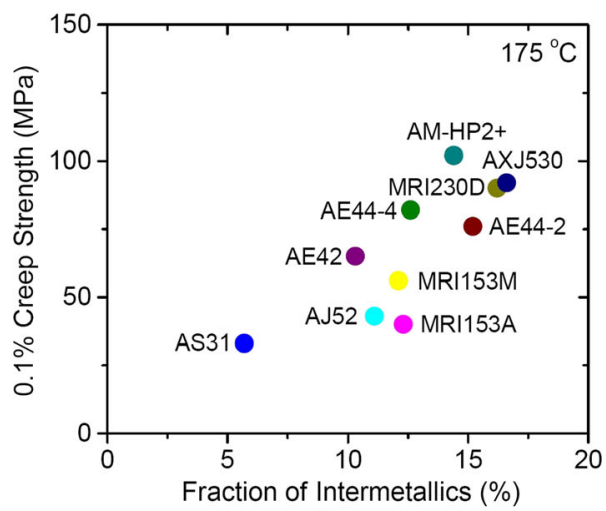

(b)

Fig. 10 - Correlation of 0.1 pct creep strength at $(a) 423 \mathrm{~K}\left(150^{\circ} \mathrm{C}\right)$ and $(b) 448 \mathrm{~K}\left(175^{\circ} \mathrm{C}\right)$ with fraction of intermetallic phases for the selected $\mathrm{Mg}$ die-casting alloys. The fraction of intermetallic phases was determined from the SEM backscattered electron images as shown in Fig. 1.

process. In the case of AZ91, the precipitate phase is $\mathrm{Mg}_{17} \mathrm{Al}_{12}$, which has poor thermal stability and tends to coarsen rapidly at elevated temperatures. The high coarsening rate, together with the high diffusion rate of $\mathrm{Al}$ in $\mathrm{Mg}$, accounts for the poor creep resistance of AZ91, despite the relatively high yield strength. On the other hand, the main precipitate phase is $\mathrm{Al}_{2} \mathrm{Ca}$ for both MRI230D ${ }^{[23]}$ and AXJ530 ${ }^{[24]}$ and probably $\mathrm{Mg}_{3} \mathrm{Nd}$ for $\mathrm{AM}-\mathrm{HP} 2+{ }^{[43]}$ With high melting points, $\mathrm{Al}_{2} \mathrm{Ca}$ and $\mathrm{Mg}_{3} \mathrm{Nd}$ are expected to have intrinsically high thermal stability and sustained precipitation strengthening at elevated temperatures, thus leading to the good creep resistance observed in MRI230D, AXJ530 and AM$\mathrm{HP} 2+$.

\section{CONCLUSIONS}

The microstructure, tensile properties, and creep resistance of the most common $\mathrm{Mg}$ die-casting alloys have been evaluated and the following conclusions can be drawn:

1. Among the selected $\mathrm{Mg}$ die-casting alloys investigated, MRI230D, AXJ530, and AM-HP2 + have higher yield strength than the Al alloy A380, but the ductility is relatively low for these alloys. In 
contrast, AS31 and the AE series alloys have very good ductility, but their yield strength is lower than that of A380. In terms of creep resistance, MRI230D, AXJ530, AE44, and AM-HP2 + are at least comparable to the $\mathrm{Al}$ alloy counterpart at both $423 \mathrm{~K}$ and $448 \mathrm{~K}\left(150{ }^{\circ} \mathrm{C}\right.$ and $\left.175^{\circ} \mathrm{C}\right)$.

2. For the $\mathrm{Mg}$ die-casting alloys, the contribution of intermetallic phase to strength not only depends on its fraction but also on its morphology. The strengthening contribution is higher when the intermetallic phase is interconnected rather than being lamellar and discontinuous. Supersaturation of solute is another factor that can contribute to the strength of the $\mathrm{Mg}$ die-casting alloys.

3. Supersaturation of solute plays a more important role in creep resistance than in the strength of the $\mathrm{Mg}$ die-casting alloys. The effect of the supersaturated solute on creep strength depends on the thermal stability of the precipitates that form during creep. A high level of solute is favored for creep resistance only when the precipitates formed are thermally stable and do not coarsen rapidly during creep.

\section{ACKNOWLEDGMENTS}

This work was supported in part by CAST Co-operative Research Centre, which was established under and supported in part by the Australian Government's Cooperative Research Centres (CRC) scheme. Monash Centre for Electron Microscopy (MCEM) is acknowledged for access to experimental facilities. The authors would like to thank Mr. Andy Yob and Mrs. Maya Gershenson of CSIRO for producing the samples used in this work. The authors also acknowledge the support of the Australian Research Council (ARC) through linkage Grant LP130100828.

\section{REFERENCES}

1. J.F. King: Mater. Sci. Technol., 2007, vol. 23, pp. 1-14.

2. C.H. Cáceres: Metall. Mater. Trans. A, 2007, vol. 38A, pp. 1649 62

3. M. Hakamada, T. Furuta, Y. Chino, Y. Chen, H. Kusuda, and M. Mabuchi: Energy, 2007, vol. 32, pp. 1352-60.

4. M.O. Pekguleryuz and M. Celikin: Int. Mater. Rev., 2010, vol. 55, pp. 197-217.

5. A.A. Luo: in Magnesium Technology 2000, H.I. Kaplan, J. Hryn, and B. Clow, eds., TMS, Warrendale, PA, 2000, pp. 89-98.

6. I.J. Polmear: Mater. Sci. Technol., 1994, vol. 10, pp. 1-16.

7. A. Luo: Int. Mater. Rev., 2004, vol. 49, pp. 13-30.

8. M. Dargusch, M.A. Easton, S.M. Zhu, and G. Wang: Mater. Sci. Eng. A, 2009, vol. 523, pp. 282-88.

9. M. Dargusch, G.L. Dunlop, and K. Pettersen: in Magnesium Alloys and Their Applications, B.L. Mordike and K.U. Kainer, eds., Verksoff-Informationsgesellschaft, Wolfsburg, Germany, 1998 , pp. $277-82$.

10. P. Humble: Mater. Forum, 1997, vol. 21, pp. 45-56.

11. M.O. Pekguleryuz and A.A. Kaya: Adv. Eng. Mater., 2003, vol. 5 , pp. $866-78$

12. K.U. Kainer: Magnesium - Alloys and Technology, Wiley, Weinheim, 1993.
13. T.K. Aune and T. Ruden: SAE Technical Paper Series, SAE, Warrendale, Paper No. 920070, 1992.

14. V.A. Agalakov: Proceedings of 6th International Conference on Magnesium Alloys and their Applications, K.U. Kainer, ed., Wiley, Weinheim, Germany, 2003, pp. 18-24.

15. M.O. Pekguleryuz and E. Baril: in Magnesium Technology 2001, J. Hryn, ed., TMS, Warrendale, PA, 2001, pp. 119-25.

16. E. Baril, P. Labelle, and M.O. Pekguleryuz: JOM, 2003, vol. 55 (11), pp. 34-39.

17. A. Luo, M.P. Balogh, and B.R. Powell: Metall. Mater. Trans. A, 2002, vol. 33A, pp. 567-74.

18. R Ninomiya, T Ojiro, and K Kubota: Acta Metall. Mater., 1995, vol. 43, pp. 669-74.

19. B.R. Powell, A. Luo, B.L. Tiwari, and V. Rezhets: in Magnesium Technology 2002, H.I. Kaplan, ed., TMS, Warrendale, PA, 2002, pp. 123-29.

20. G. Cao and S. Kou: Metall. Mater. Trans. A, 2006, vol. 37A, pp. 3647-63.

21. F. Von Buch, S. Schumann, H. Friedrich, E. Aghion, B. Bronfin, B.L. Mordike, M. Bamberger, and A. Eliezer: in Magnesium Technology 2002, H.I. Kaplan, ed., TMS, Warrendale, PA, 2002, pp. 61-68.

22. E. Aghion and B. Bronfin: Proceedings of the Third International Magnesium Conference, G.W. Lorimer, ed., Institute of Materials, Manchester, U.K., 1996, pp. 314-25.

23. B. Backes, K. Durst, D. Amberger, and M. Göken: Metall. Mater. Trans. A, 2009, vol. 40A, pp. 257-61.

24. A. Suzuki, N.D. Saddock, J.R. TerBush, B.R. Powell, J.W. Jones, and T.M. Pollock: Metall. Mater. Trans. A, 2008, vol. 39A, pp. 696-702.

25. W.E. Mercer II: SAE Technical Paper Series, SAE, Warrendale, Paper No. 900788, 1990.

26. E.G. Sieracki, J.J. Velazquez, and K. Kabiri: SAE Technical Paper Series, SAE, Warrendale, 1996, Paper No. 960421.

27. L. Bichler, C. Ravindran, and D. Sediako: Can. Metall. Q., 2009, vol. 48, pp. 81-90.

28. P. Bakke and H. Westengen: in Magnesium Technology 2005, N.R. Neelameggham, H.I. Kaplan, and B.R. Powell, eds., TMS, Warrendale, PA, 2005, pp. 291-96.

29. B.R. Powell, V. Rezhets, M.P. Balogh, and R.A. Waldo: JOM, 2002, vol. 54 (8), pp. 34-38.

30. J. Zhang, K. Liu, D. Fang, X. Qiu, D. Tang, and J. Meng: J. Mater. Sci., 2009, vol. 44, pp. 2046-54.

31. J. Zhang, P. Yu, K. Liu, D. Fang, D. Tang, and J. Meng: Mater. Des., 2009, vol. 30, pp. 2372-78.

32. L. Jin, D. Kevorkov, M. Medraj, and P. Chartrand: J. Chem. Thermodyn., 2013, vol. 58, pp. 166-95.

33. P. Lyon, J.F. King, and K. Nuttall: Proceedings of the Third International Magnesium Conference, G.W. Lorimer, ed., Institute of Materials, Manchester, U.K., 1996, pp. 99-108.

34. I.P. Moreno, T.K. Nandy, J.W. Jones, J.E. Allison, and T.M. Pollock: in Magnesium Technology 2002, H.I. Kaplan, ed., TMS, Warrendale, 2002, pp. 111-16.

35. S.M. Zhu, M.A. Gibson, M.A. Easton, and J.F. Nie: Scripta Mater., 2010, vol. 63, pp. 698-703.

36. T.L. Chia, M.A. Easton, S.M. Zhu, M.A. Gibson, N. Birbilis, and J.F. Nie: Intermetallics, 2009, vol. 17, pp. 481-90.

37. M.A. Gibson, M.A. Easton, V. Tyagi, M.T. Murray, and G.L. Dunlop:, in Magnesium Technology 2008, M.O. Pekguleryuz, N.R. Neelameggham, R. Beals, and E.A. Nyberg, eds., TMS, Warrendale, 2008, pp. 227-32.

38. W. Sequeira, G.L. Dunlop, and M.T. Murray: Proceedings of the Third International Magnesium Conference, G.W. Lorimer, ed., Institute of Materials, Manchester, U.K., 1996, pp. 63-73.

39. A.K. Dahle, Y.C. Lee, M.D. Nave, P.L. Schaffer, and D.H. StJohn: J. Light Met., 2001, vol. 1, pp. 61-72.

40. S.M. Zhu, M.A. Easton, M.A. Gibson, M.S. Dargusch, and J.F. Nie: Mater. Sci. Eng. A, 2013, vol. 578, pp. 377-82.

41. M. Kunst, A. Fischersworring-Bunk, G. L'Esperance, P. Plamondon, and U. Glatzel: Mater. Sci. Eng. A, 2009, vols. 510511, pp. 387-92.

42. S.M. Zhu, M.A. Gibson, J.F. Nie, M.A. Easton, and T.B. Abbott: Scripta Mater., 2008, vol. 58, pp. 477-80.

43. S.M. Zhu, M.A. Gibson, J.F. Nie, M.A. Easton, and G.L. Dunlop: Metall. Mater. Trans. A, 2009, vol. 40A, pp. 2036-41. 
44. W. Blum, Y.J. Li, X.H. Zeng, P. Zhang, B. von Großmann, and C. Haberling: Metall. Mater. Trans. A, 2005, vol. 36A, pp. 1721-28. 45. S. Spigarelli: Mater. Sci. Eng. A, 2009, vol. 492, pp. 153-60.

46. J.W. Martin: Micromechanisms in Particle-hardened Alloys, Cambridge University Press, Cambridge, UK, 1980.

47. L.M. Brown and D.R. Clarke: Acta Mater., 1975, vol. 27, pp. $821-$ 30 .

48. M.A. Gharghouri, G.C. Weatherly, J.D. Embury, and J. Roort: Philos. Mag. A, 1999, vol. 79, pp. 1671-95.

49. C.H. Cáceres, C.J. Davidson, J.R. Griffiths, and C.L. Newton: Mater. Sci. Eng. A, 2002, vol. 325, pp. 344-55.

50. M. Dargusch, K. Pettersen, K. Nogita, M.D. Nave, and G.L. Dunlop: Mater. Trans., 2006, vol. 47, pp. 977-82.

51. B. Zhang, A.V. Nagasekhar, T. Sivarupan, and C.H. Caceres: $A d v$. Eng. Mater., 2013, vol. 15, pp. 1059-67.

52. B. Zhang, A.V. Nagasekhar, X. Tao, Y. Ouyang, C.H. Cáceres, and M. Easton: Mater. Sci. Eng. A, 2014, vol. 599, pp. 204-11.
53. B. Zhang, S. Gavras, A.V. Nagasekhar, C.H. Cáceres, and M.A. Easton: Metall. Mater. Trans. A, 2014, vol. 45A, pp. 4386-97.

54. S.M. Zhu, J.F. Nie, M.A. Gibson, M.A. Easton, and P. Bakke: Metall. Mater. Trans. A, 2012, vol. 43A, pp. 4137-44.

55. K.V. Yang, C.H. Cáceres, and M.A. Easton: Metall. Mater. Trans. A, 2014, vol. 45A, pp. 4117-28.

56. G.V. Raynor: The Physical Metallurgy of Magnesium and Its Alloys, Pergamon Press, London, 1959.

57. E.F. Emley: Principles of Magnesium Technology, Pergamon Press, London, 1966

58. R.L. Bell and T.G. Langdon: J. Mater. Sci., 1967, vol. 2, pp. 313-23.

59. D. Amberger, P. Eisenlohr, and M. Goken: Acta Mater., 2012, vol. 60, pp. 2277-89.

60. K. Maruyama, M. Suzuki, and H. Sato: Metall. Mater. Trans. A, 2002, vol. 33A, pp. 875-82.

61. W. Blum, B. Watzinger, and P. Zhang: Adv. Eng. Mater., 2000, vol. 2, pp. 349-55. 